\title{
Protective Effect of Resveratrol Against Morphine Damage to Kidneys of Mice
}

\author{
Efecto Protector de Resveratrol contra el Daño de la Morfina en Riñones de Ratones
}

Cyrus Jalili'; Fatemeh Makalanii'; Shiva Roshankhah'; Khadije Sohrabi ${ }^{2}$ \& Mohammad Reza Salahshoor ${ }^{1}$

JALILI, C.; MAKALANI, F.; ROSHANKHAH, S.; SOHRABI, K. \& SALAHSHOOR, M. R. Protective effect of resveratrol against morphine damage to kidneys of mice. Int. J. Morphol., 35(4):1409-1415, 2017.

SUMMARY: Morphine produces free radicals and cause apoptosis in some cell. Resveratrol (RSV) is a stilbenoid, a type of natural phenol, and a phytoalexin produced by several plants in response to injury. 48 male mice were randomly assigned to 8 groups. In this study, various doses of RSV (2,8 and $20 \mathrm{mg} / \mathrm{kg}$ ) and RSV plus Morphine (2,8 and $20 \mathrm{mg} / \mathrm{kg}$ ) were administered intraperitoneally to male mice for 20 consequent days and weight of kidneys, biochemical characteristics, morphometric markers and blood serum nitric oxide level were studied. The results indicated that morphine administration significantly increased the mean diameter of glomerulus and distal and proximal convoluted tubule, Lactate dehydrogenase (LDH), Blood urea nitrogen (BUN), creatinine and nitric oxide levels compared to the saline group $(\mathrm{P}<0.05)$. However, RSV and RSV plus morphine in all doses significantly decreased glomeruli number and LDH, BUN, creatinine and nitric oxide levels compared to morphine groups $(\mathrm{p}<0.05)$. Thus, it seems that resveratrol improved kidney damages induced by morphine in mice.

KEY WORDS: Morphine; Resveratrol; Kidney.

\section{INTRODUCTION}

Polyphenolic compounds have gained much attention due to their profound health benefits Resveratrol (3, 5, 4'trihydroxy-trans-stilbene) is a polyphenolic phytoalexin, which can be found in a number of fruits and nutritional sources and in various plants, including grapes, berries and peanuts (Finnell et al., 2017). It is also present in win (Rafati et al., 2015). Resveratrol has been the focus of numerous studies investigating its biological attributes, which include mainly antioxidant activities (Chu et al., 2016). RSV is a polyphenolic compound that has demonstrated antiinflammatory and antioxidant effects, resulting from enhanced antioxidant enzymes production and modulating nuclear factors involved in the inflammation-oxidative stress cycle, as nuclear erythroid 2-related factor 2 (Nrf2) and nuclear factor-kB (NF-kB) (Saldanha et al., 2016). Pandey \& Rizvi (2011) reported potent antioxidant activity of resveratrol, its antioxidant activity that has demonstrated to protect tissues, such as liver, kidney and brain against a variety of damage caused by oxidative stress. Resveratrol inhibits effectively the lipid peroxidation of cellular membranes, the protein oxidation as well as the DNA damage due its ability to directly scavenge various free radicals, including superoxide radicals and peroxyl and hydroxyl radicals (Schmatz et al., 2012). Opioids produce free radicals and cause apoptosis in some cell. Morphine is an opioid analgesic drug, and the main psychoactive chemical in opium (Salahshoor et al., 2016). Morphine is addictive cause physiological dependence (Jalili et al., 2016). Long-term opioid use is associated with undesirable consequences including renal function (Jalili et al., 2017). Morphine is a strong analgesic that is absorbed and metabolized in the liver and digestive system and is finally excreted through kidneys (Lan et al., 2013). Morphine can increase the production of free radicals by activating lipid peroxidation, thereby blocking the antioxidant enzymes and forming free radicals or reactive oxygen species (Ahmadizadeh et al., 2012). The studies of Malekpourafshar \& Zeinalinejad (2005) show that morphine can remarkably damage the kidneys and increase microinjection of podocytes in kidneys. Morphine can also cause the stimulation of diuretic hormone release from kidneys and vascular vasodilation. Considering the destructive effects of morphine and antioxidant properties

\footnotetext{
${ }^{1}$ Department of Anatomical Sciences, Medical School, Kermanshah University of Medical Sciences, Kermanshah, Iran.

${ }^{2}$ Students research committee, Kermanshah university of Medical Sciences. Daneshgah Ave., Taghbostan, Kermanshah, Iran.
} 
of resveratrol, and that no study has ever evaluated the effects of resveratrol on morphine-induced damages, this study was aimed to assess the effects of resveratrol on morphineinduced impairments and renal dysfunctions in mice.

\section{MATERIAL AND METHOD}

Animals. Forty-eight Balb/c male mice with a weight range of $25 \pm 2 \mathrm{~g}$, were used for the present study. Purchased from Tehran Razi institute. Animals were kept at the animal house for one week before the commencement of the study under laboratory conditions at $20 \pm 2{ }^{\circ} \mathrm{C}, 12 / 12 \mathrm{~h}$ light/ dark cycle and free access to water and food. 6 mice in each cage were kept in the standard cages. The experiments were carried out in accordance with the guidelines provided by the Ethics Committee of Kermanshah University of Medical Sciences (Salahshoor et al.).

Experimental design. The animals were randomly divided into 8 groups $(\mathrm{n}=6)$. Group 1 , saline group, received 0.9 $\%$ normal saline daily, Group 2 . Morphine group, received morphine. Groups 3 to 5 (resveratrol groups) were given 2,8 and $20 \mathrm{mg} / \mathrm{kg}$ resveratrol. Mice in groups 6 to 8 received resveratrol $(2,8$ and $20 \mathrm{mg} / \mathrm{kg})$ plus morphine. Morphine administered by interaperitoneally injecting as follows: $20 \mathrm{mg} / \mathrm{kg}$ once daily within the first 5 days and twice per day within the next 5 days. On days 11-20, a dose of up to $30 \mathrm{mg} / \mathrm{kg}$ twice per day. Mice with resveratrol as follows: On days 1-20, Resveratrol once daily, interaperitoneally injecting. Mice with morphine plus resveratrol as follows: On days 1-20, resveratrol once daily plus morphine, interaperitoneally injecting. The same volume of saline was administered (Ranawat et al., 2014; Jalili et al., 2017).

Chemicals. Resveratrol (3, 5, 4'-trihydroxy-trans-stilbene) (Merck-Germany) was dissolved in ethanol and diluted by normal saline $(0.9 \%)$ to prepare different doses. Morphine (C16H19NO3) was obtained from Sigma Chemical Company (St. Louis, USA) and was dissolved in saline $(0.9 \%)$ for administration.

Biochemical Assays and measurement of kidney weight. All animals were anesthetized with chloroform, Midline laparotomy was performed and kidney specimens were obtained. Blood samples were drawn by cardiac puncture and were incubated at $37^{\circ} \mathrm{C}$ to coagulate. The coagulated blood samples were then centrifuged for $15 \mathrm{~min}$ at 3000 rpm until the serum was separated. The separated serum was kept at $-20^{\circ} \mathrm{C}$ until the measurement of biochemical factors and nitric oxide levels. Serum LDH, creatinine and
BUN levels were measured by an autoanalyzer (Access Random Liasys) using a kit (PARS -AZMON). Animals were killed and sacrificed. Kidney removed and weighted on a microbalance sensitive to $0.001 \mathrm{mg}$ (Precisa 125A, Switzerland) (Najafi et al., 2015; Jalili et al., 2017).

Griess method. Nitric oxide in serum samples were determined by Griess staining method. To measure nitrite concentration in serum, in this assay after de-freezing the serum samples, supernatant $(400 \mathrm{ml})$ was deproteinized with zinc sulfate. Then, $100 \mathrm{ml}$ supernatant was taken and $100 \mathrm{ml}$ vanadium chloride, $50 \mathrm{ml}$ solfanile amide and 50 $\mathrm{ml}$ NEDD (N-1 (naphtylen) ethylenediamine dihydrochoride) were added. Standard solutions of sodium nitrate prepared with different concentrations of nitrate. Samples' optical density (OD) was assessed using ELISA reader at the wavelength of $540 \mathrm{~nm}$ (Jalili et al., 2015).

Histological and morphometric examinations. Kidney tissues were fixed in $10 \%$ formalin solution for 72 hour then dehydrated in a grated series of ethanol cleared in xylene and embedded in paraffin wax. Microtome sections (5 mm thick) (Leica RM 2125, Leica Microsystems Nussloch, Germany) were prepared from kidney samples and stained with Hematoxylin and eosin and evaluated by light microscopy. From each sample, 5 sections, 3 fields view from each slide for analyzing diameter of glomerulus, distal and proximal convoluted tubule and glomerulus number using an Olympus BX-51T-32E01 research microscope connected to a DP12 Camera with 3.34-million pixel resolution and Olysia Bio software (Olympus Optical, Tokyo, Japan) (Salahshoor et al.; Jalili et al., 2017).

Data analysis. One-way analysis of variance (ANOVA) and Tukey tests were used to perform the statistical analysis of experimental groups compared to control group.

\section{RESULTS}

The effect of morphine caused a significant decrease in the kidney weight of the mice compared to -saline group $(\mathrm{p}<0.05)$. Resveratrol and resveratrol plus morphine increased the kidney weight in all doses in comparison with morphine group $(\mathrm{p}<0.05)$ (Fig. 1).

Further, morphine significantly increased the mean diameter of glomerulus and distal and proximal convoluted tubule $(\mathrm{p}<0.05)$. Moreover, resveratrol and resveratrol plus morphine significantly decreased the diameter of glomeruli and distal and proximal convoluted tubule compared to morphine group $(\mathrm{p}<0.05)$ (Fig. 2). 


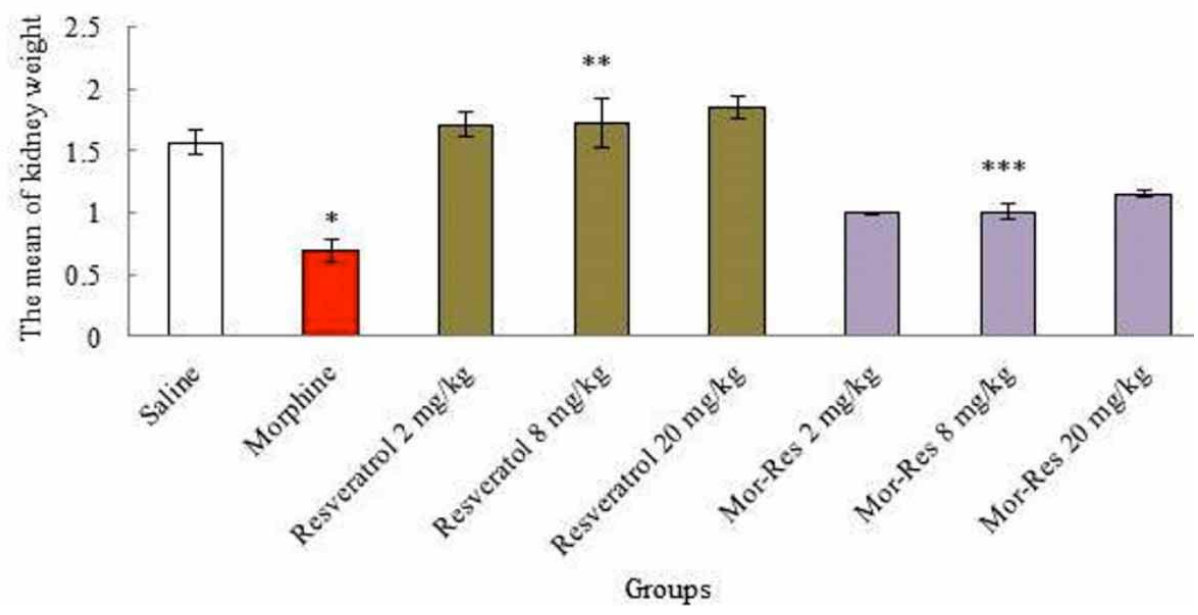

Fig. 1. Forty-eight mice were equally divided into 8 groups.*Significant decrease of kidney weight in morphine group compared to saline group $(\mathrm{P}<0.05)$.**Significant increase in all doses of resveratrol compared to morphine group $(\mathrm{P}<0.05)$. ***Significant increase in all doses of resveratrol plus morphine compared to morphine group $(\mathrm{P}<0.05)$.
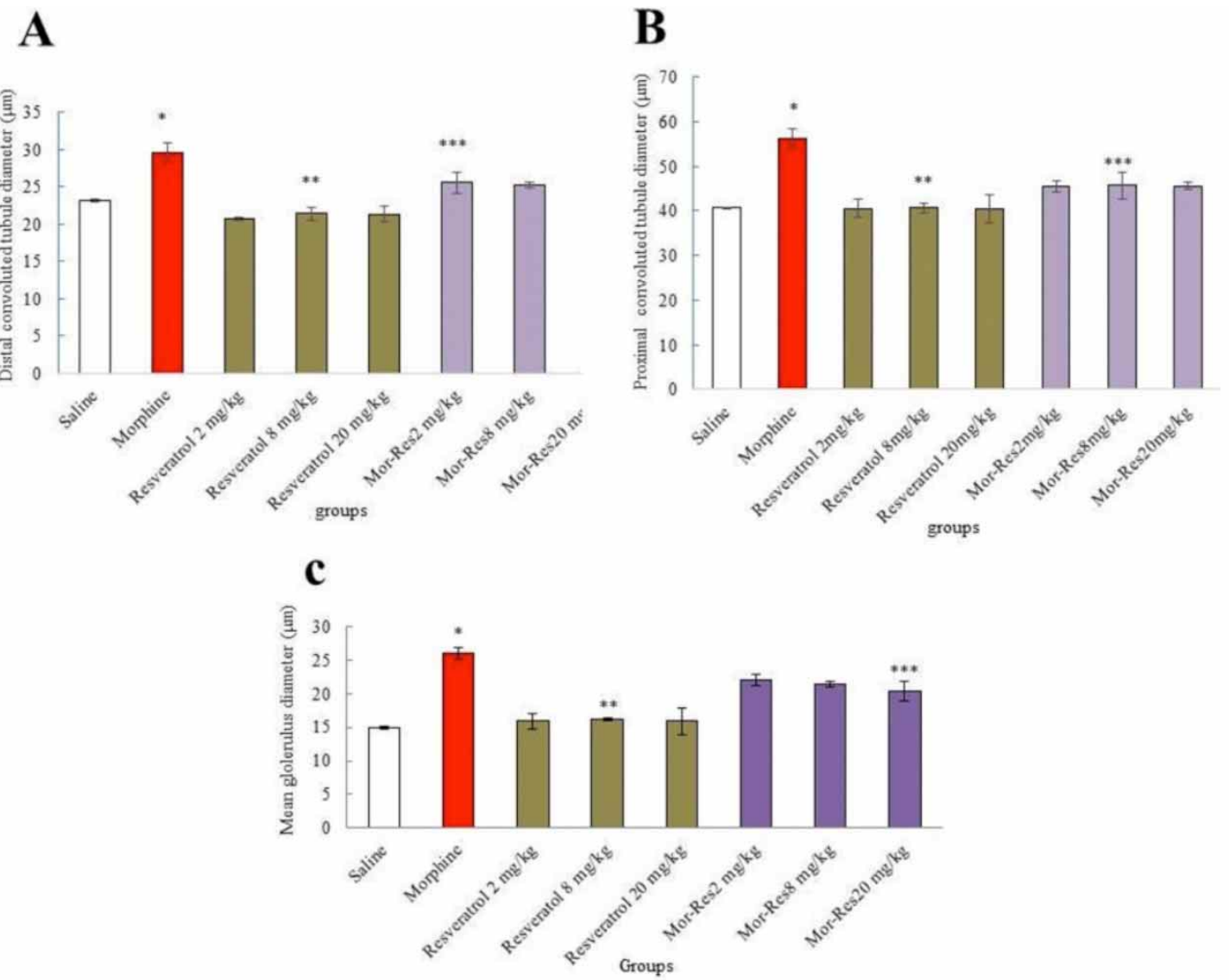

Fig. 2. Effect of morphine, resveratrol and resveratrol plus morphine administration on kidney morphometric examinations. A; the mean diameter of distal convoluted tubule, B; the mean diameter of proximal convoluted tubule $\mathrm{C}$; the mean diameter of glomerulus. *Significant increase of morphometric examinations in morphine groups compared to saline groups $(\mathrm{P}<0.05)$. **Significant decrease of morphometric examinations in all doses of resveratrol compared to morphine groups administration $(\mathrm{P}<0.05)$. ***Significant decrease of morphometric examinations in all doses of resveratrol plus morphine compared to morphine groups $(\mathrm{P}<0.05)$. 
The findings of BUN, creatinine, LDH enzymes and NO blood serum measurement indicated a significant increase between saline group and morphine $(\mathrm{p}<0.05)$. Moreover, resveratrol and resveratrol plus morphine significantly decreased the blood serum of BUN, creatinine, $\mathrm{LDH}$ and $\mathrm{NO}$ in all groups compared to morphine group $(\mathrm{p}<0.05)$ (Fig. 3).

\section{A}
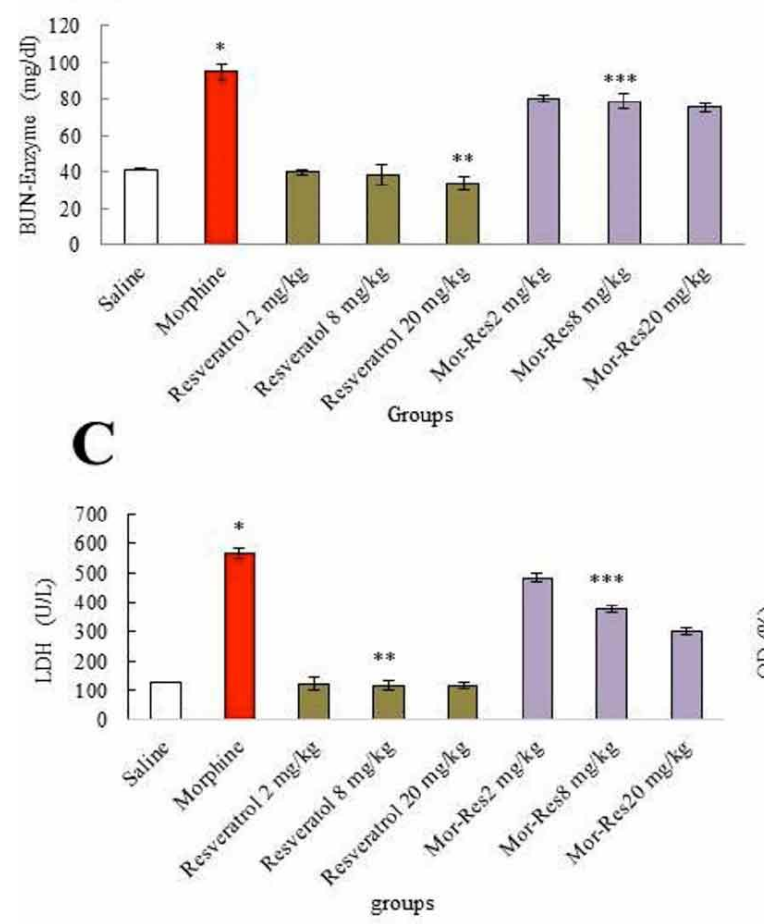

In addition, morphine caused a significant decrease in the glomeruli number in comparison with saline group $(\mathrm{p}<0.05)$. However, resveratrol and resveratrol plus morphine significantly increased number of glomeruli in all doses compared to morphine group ( $\mathrm{p}<0.05)$ (Fig. 4).

Fig. 3. Effect of morphine, resveratrol and resveratrol plus morphine administration on the mean of kidney biochemical factors. A; BUN enzyme B; creatinine enzyme C; LDH enzyme D; blood serum NO. *Significant increase of the biochemical factor levels in morphine groups compared to saline groups $(\mathrm{P}<0.05)$. **Significant decrease of the biochemical factor levels in all doses of resveratrol administration compared to morphine groups $(\mathrm{P}<0.05)$. ***Significant decrease of the biochemical factor levels in all doses of resveratrol plus morphine administration compared to morphine groups $(\mathrm{P}<0.05)$.

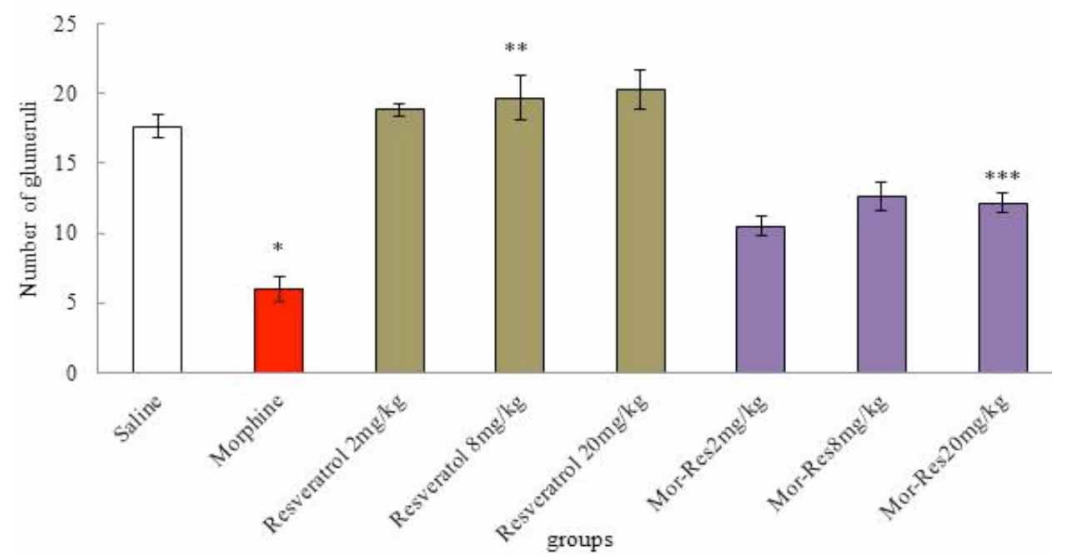

1412
Fig. 4. Correlation analysis between treatment groups (resveratrol, morphine and resveratrol plus morphine) in mice and glomeruli number. *Significant increase in Morphine group compared to Saline group $(\mathrm{p}<0.05)$. ** Significant decrease in all doses resveratrol groups compared to morphine group $(\mathrm{p}<0.05)$. *** Significant decrease in all doses resveratrol plus morphine groups compared to morphine group $(\mathrm{p}<0.05)$. 
Also, histological examination showed normal kidney structure in the saline and resveratrol groups. After treatment with morphine, the kidney section appeared with variable changes and marked injury. These abnormalities included expanded space of Bowman's capsule, glomerulus shrinkage, intertubular bleeding and increased diameter of distal and proximal tubules. After treatment with morphine plus resveratrol in all doses, it was recognized that resveratrol reduced kidney injury caused by morphine toxicity (Fig. 5).

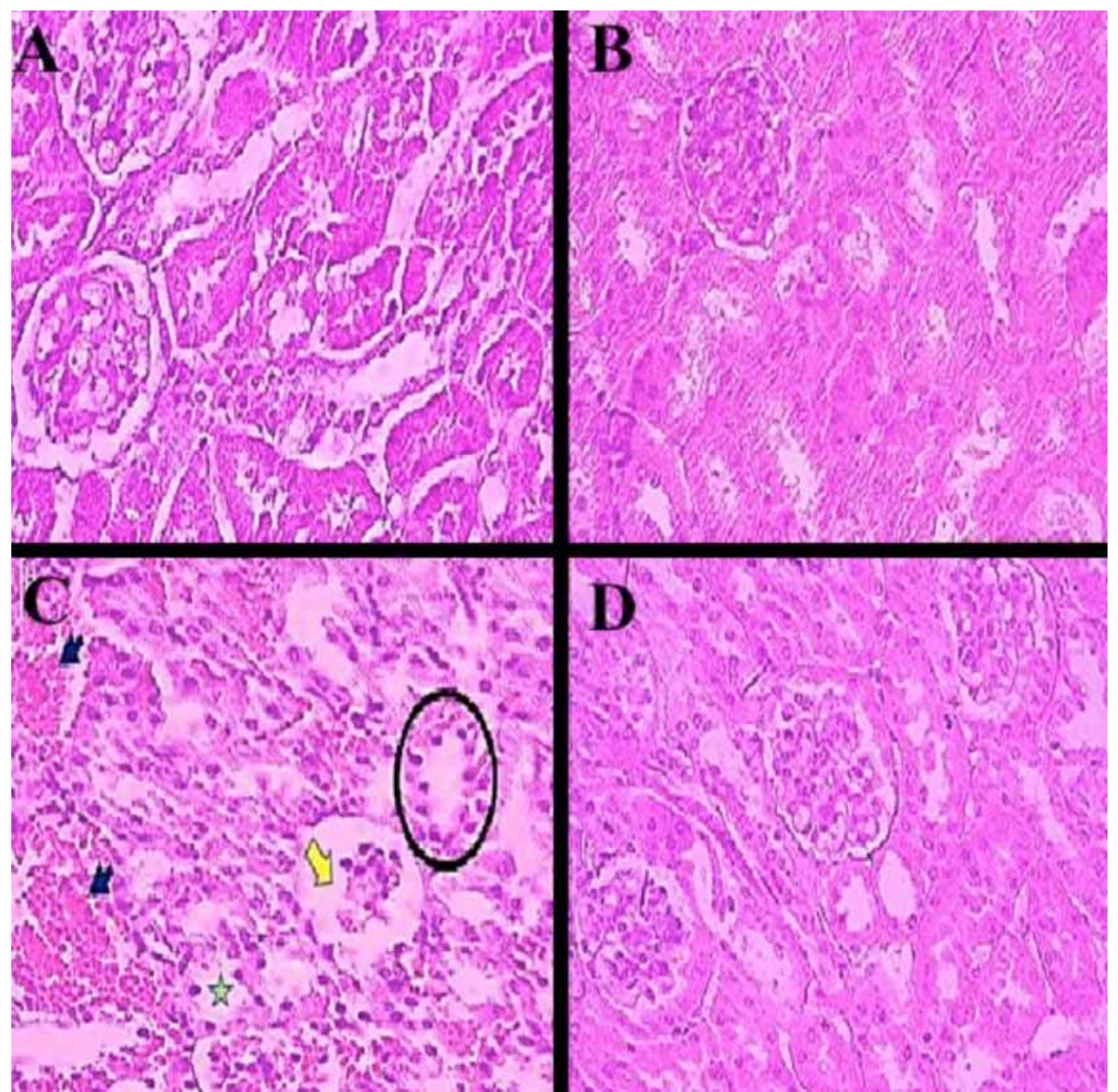

Fig. 5. Histological changes of the kidneys (hematoxylin-eosin, ¥ 100). A, Normal kidney structure in the saline group. B, Normal kidney structure in the group treated with resveratrol, $20 \mathrm{mg} / \mathrm{kg}$. Glomeruli with Bowman's capsule and distal and proximal tubules were observed in a specific range. C, in morphine group, increased Bowman's capsule space and glomerular shrinkage (yellow arrow), intertubular bleeding (black arrows), increased diameter of distal (star) and proximal (circle) tubules were seen. D, Normal kidney structure in the group treated with morphine plus resveratrol, $20 \mathrm{mg} / \mathrm{kg}$.

\section{DISCUSSION}

Morphine is an analgesic that is used clinically to alleviate severe pain. It is biotransformed in liver, digestive tubes and kidney and is excreted through kidney. Morphine can be metabolized into free radicals and can damage different body organs by increasing dopamine, xanthine oxidase and reactive oxygen species (Samarghandian et al., 2014). In the present study, the protective effects of resveratrol on morphine-induced disorders and renal histomorphometry (kidney weight, diameter and number of glomeruli and renal tubules and biochemical factors of blood) were evaluated in mice. Lan et al. reported the toxic effects of morphine on kidney, which is in line with the results of current study. In the present study, the results of kidney weight measurement in the study groups indicated that morphine administration reduced the mean weight of kidneys. These effects, however, were significantly reduced by resveratrol administration. Morphine can decrease the kidney weight by damaging the kidneys and disturbing the metabolism of mice. Also, reduced weight of kidneys can be associated with decreased number of glomeruli due to morphine administration (Atici et al., 2005). It seems that resveratrol has antioxidant properties and inhibitory effects on free radicals. Its antioxidant ability is dependent on the properties of hydroxyl polyphenol groups, through which it can neutralize the effects of morphine (Kasdallah-Grissa et al., 2006; Ghanim et al., 2010) showed that resveratrol has protective effects against ethanolinduced oxidative stress in testis tissue, confirming the findings of the present research. The results of current study revealed that morphine administration increased the diameter of glomeruli and renal tubules and decreased the number of glomeruli compared to the saline-receiving group. These effects were partly eliminated by resveratrol administration. Morphine can cause dysfunction and impairment of renal 
glomeruli and podocytes by affecting the filtration of glomeruli and their number, diameter and structure through superoxide production by macrophages and DNA damage (Singhal et al., 1994). It seems that resveratrol, as an antioxidant, can inhibit apoptotic induction and DNA damage against oxidative stress resulting from some materials (Revel et al., 2001). The results of the study by Jalili et al. (2017) confirm the findings of the present study in that thymoquinone, as an antioxidant, can eliminate the toxic effects of morphine. The results of the current study showed the increased level of enzymes in morphine-receiving group, which was reduced in the blood sample of study groups by resveratrol administration. The effects of resveratrol in reducing creatinine level and improving pathologic changes of kidney seem to be associated with activation of Sirt 1 and reduced expression of Smad 3 (Huang et al., 2014). Resveratrol can reduce renal impairment by inhibition of renal fibrosis and downregulation of accumulation of macrophages and expression of IL-6, ICAM and MCP-1. It seems that resveratrol, as an anti-fibrotic factor, is able to prevent renal damage (Xue et al., 2016). The results of this study indicated that nitric oxide level in blood serum of groups receiving morphine was significantly increased compared with saline group, and resveratrol administration could reduce the effects of morphine on NO level. The molecular mechanism shows that morphine induces increased NO production through intracellular regulation of calcium and activation of calcium/ calmodulin-dependent NOS. Nitric oxide is a free radical that is produced in mammalian cells and is involved in the regulation of physiologic processes, and its increase is followed by various diseases (Jalili et al., 2016). As an antioxidant and a scavenger of free radicals, resveratrol can increase the activity of antioxidant enzymes. Resveratrol can reduce the production of $\mathrm{NO}$ and induction of NOS isoforms such as iNOS and can inhibit the activity of iNOS activating enzymes by affecting oxidative stress and nitrosative in microglial cells (de la Lastra \& Villegas, 2007). The findings of the current study showed that resveratrol, as an antioxidant, can have beneficial effects against morphineinduced impairments, which are mainly due to oxidative stress induction.

\section{CONCLUSION}

The present study showed that resveratrol can significantly improve impairments resulting from the toxicity of morphine in the kidneys. The results also suggest the protective of resveratrol antioxidant effects against toxic effects of morphine-treated male mice. Further research in animal models is required for a better understanding for the molecular interaction between resveratrol and morphine mechanism.

\section{ACKNOWLEDGMENTS}

We gratefully acknowledge the Research Council of Kermanshah University of Medical Sciences (no: 94416) for the financial support. This work was performed in partial fulfillment of the requirements for MD of Khadije Sohrabi in the faculty of medicine, Kermanshah University of Medical Sciences, Kermanshah, Iran.

JALILI, C.; MAKALANI, F.; ROSHANKHAH, S.; SOHRABI, K. \& SALAHSHOOR, M. R. Efecto protector de resveratrol contra el daño de la morfina en riñones de ratones. Int. J. Morphol., 35(4):1409-1415, 2017.

RESUMEN: La morfina produce radicales libres y causa apoptosis en algunas células. El resveratrol (RSV) es un tipo de fenol natural y una fitoalexina producida por varias plantas en respuesta a una lesión. Se asignaron al azar 48 ratones machos a 8 grupos. En este estudio se administraron varias dosis de RSV (2, 8 y $20 \mathrm{mg} / \mathrm{kg}$ ) y RSV más morfina $(2,8$ y $20 \mathrm{mg} / \mathrm{kg})$ intraperitoneal en ratones machos durante 20 días consecutivos y se estudió el peso de los riñones, las características bioquímicas, los marcadores morfométricos y el nivel de óxido nítrico en suero sanguíneo. Los resultados indicaron que la administración de morfina aumentó significativamente el diámetro medio del glomérulo y de los túbulos distal y proximal, los niveles de lactato deshidrogenasa (LDH), nitrógeno ureico en sangre (BUN), la creatinina y el óxido nítrico en comparación con el grupo salino ( $\mathrm{p}<0,05$ ). Sin embargo, el RSV y el RSV más morfina en todas las dosis redujeron significativamente el número de glomérulos y LDH, BUN, la creatinina y el óxido nítrico en comparación con los grupos de morfina $(\mathrm{p}<0,05)$. Por lo tanto, los resultados podrían indicar que el resveratrol mejoró el daño renal inducido por la morfina en ratones.

PALABRAS CLAVE: Morfina; Resveratrol; Riñon.

\section{REFERENCES}

Ahmadizadeh, M.; Sarkaki, A. R.; Farboud, Y.; Mohammadian, B. \& Rahim, F. Effect of exercise on morphine-induced toxicity in rat liver and kidney. Jundishapur Sci. Med. J., 11(3):325-33, 2012.

Atici, S.; Cinel, I.; Cinel, L.; Doruk, N.; Eskandari, G. \& Oral, U. Liver and kidney toxicity in chronic use of opioids: an experimental long term treatment model. J. Biosci., 30(2):245-52, 2005.

Chu, C.; Lu, F. J.; Yeh, R. H.; Li, Z. L. \& Chen, C. H. Synergistic antioxidant activity of resveratrol with genistein in high-glucose treated MadinDarby canine kidney epithelial cells. Biomed. Rep., 4(3):349-54, 2016.

de la Lastra, C. A. \& Villegas, I. Resveratrol as an antioxidant and prooxidant agent: mechanisms and clinical implications. Biochem. Soc. Trans., 35(Pt. 5):1156-60, 2007.

Finnell, J. E.; Lombard, C. M.; Melson, M. N.; Singh, N. P.; Nagarkatti, M.; Nagarkatti, P.; Fadel, J. R.; Wood, C. S. \& Wood, S. K. The protective effects of resveratrol on social stress-induced cytokine release and depressive-like behavior. Brain Behav. Immun., 59:147-57, 2017.

Ghanim, H.; Sia, C. L.; Abuaysheh, S.; Korzeniewski, K.; Patnaik, P.; Marumganti, A.; Chaudhuri, A. \& Dandona, P. An antiinflammatory 
and reactive oxygen species suppressive effects of an extract of Polygonum cuspidatum containing resveratrol. J. Clin. Endocrinol. Metab., 95(9):E1-8, 2010.

Huang, X. Z.; Wen, D.; Zhang, M.; Xie, Q.; Ma, L.; Guan, Y.; Ren, Y.; Chen, J. \& Hao, C. M. Sirt1 activation ameliorates renal fibrosis by inhibiting the TGF-b/Smad3 pathway. J. Cell. Biochem., 115(5):996$1005,2014$.

Jalili, C.; Ahmadi, S.; Roshankhah, S. \& Salahshoor, M. Effect of Genistein on reproductive parameter and serum nitric oxide levels in morphinetreated mice. Int. J. Reprod. Biomed. (Yazd.), 14(2):95-102, 2016.

Jalili, C.; Salahshoor, M. R. \& Naderi, T. The effect of hydroalcoholic extract of P. crispum on sperm parameters, testis tissue and serum nitric oxide levels in mice. Adv. Biomed. Res., 4:40, 2015.

Jalili, C.; Salahshoor, M.R.; Hoseini, M.; Roshankhah, S.; Sohrabi, M. \& Shabanizadeh, A. Protective effect of thymoquinone against morphine injuries to kidneys of mice. Iran. J. Kidney Dis., 11(2):142-50, 2017.

Kasdallah-Grissa, A.; Mornagui, B.; Aouani, E.; Hammami, M.; Gharbi, N.; Kamoun, A. \& El-Fazaa, S. Protective effect of resveratrol on ethanol-induced lipid peroxidation in rats. Alcohol Alcohol., 41(3):2369, 2006.

Lan, X.; Rai, P.; Chandel, N.; Cheng, K.; Lederman, R.; Saleem, M. A.; Mathieson, P. W.; Husain, M.; Crosson, J. T.; Gupta, K.; Malhotra, A. \& Singhal, P. C. Morphine induces albuminuria by compromising podocyte integrity. PLoS One, 8(3):e55748, 2013.

Malekpourafshar, R. \& Zeinalinejad, H. Effect of short time morphine addiction on the kidney tissue in rat. Am. J. Biochem. Biotechnol., 1(4):186-8, 2005.

Najafi, H.; Changizi Ashtiyani, S.; Sayedzadeh, S. A.; Mohamadi Yarijani, Z. \& Fakhri, S. Therapeutic effects of curcumin on the functional disturbances and oxidative stress induced by renal ischemia/reperfusion in rats. Avicenna J. Phytomed., 5(6):576-86, 2015.

Pandey, K. B. \& Rizvi, S. I. Anti-oxidative action of resveratrol: Implications for human health. Arab. J. Chem., 4(3):293-8, 2011.

Rafati, A.; Hoseini, L.; Babai, A.; Noorafshan, A.; Haghbin, H. \& KarbalayDoust, S. Mitigating effect of resveratrol on the structural changes of mice liver and kidney induced by cadmium; a stereological study. Prev. Nutr. Food Sci., 20(4):266-75, 2015.

Ranawat, P.; Khanduja, K. L. \& Pathak, C. M. Resveratrol - an ingredient of red wine abrogates the reproductive capacity in male mice. Andrologia, 46(6):650-8, 2014.

Revel, A.; Raanani, H.; Younglai, E.; Xu, J.; Han, R.; Savouret, J. F. \& Casper, R. F. Resveratrol, a natural aryl hydrocarbon receptor antagonist, protects sperm from DNA damage and apoptosis caused by benzo(a)pyrene. Reprod. Toxicol., 15(5):479-86, 2001.

Salahshoor, M. R.; Khashiadeh, M.; Roshankhah, S.; Kakabaraei, S. \& Jalili, C. Protective effect of crocin on liver toxicity induced by morphine. Res. Pharm. Sci., 11(2):120-9, 2016.

Saldanha, J. F.; Leal, V. O.; Rizzetto, F.; Grimmer, G. H.; Ribeiro-Alves, M.; Daleprane J. B.; Carraro-Eduardo, J. C. \& Mafra, D. Effects of resveratrol supplementation in Nrf2 and NF-kB expressions in nondialyzed chronic kidney disease patients: a randomized, doubleblind, placebo-controlled, crossover clinical trial. J. Ren. Nutr., 26(6):401-6, 2016.

Samarghandian, S.; Afshari, R. \& Farkhondeh, T. Effect of long-term treatment of morphine on enzymes, oxidative stress indices and antioxidant status in male rat liver. Int. J. Clin. Exp. Med., 7(5):144953, 2014.

Schmatz, R.; Perreira, L. B.; Stefanello, N.; Mazzanti, C.; Spanevello, R.; Gutierres, J.; Bagatini, M.; Martins, C. C.; Abdalla, F. H.; Daci da Silva Serres, J.; Zanini, D.; Vieira, J. M.; Cardoso, A. M.; Schetinger, M. R. \& Morsch, V. M. Effects of resveratrol on biomarkers of oxidative stress and on the activity of delta aminolevulinic acid dehydratase in liver and kidney of streptozotocin-induced diabetic rats. Biochimie, 94(2):374-83, 2012.

Singhal, P. C.; Pamarthi, M.; Shah, R.; Chandra, D. \& Gibbons, N. Morphine stimulates superoxide formation by glomerular mesangial cells. Inflammation, 18(3):293-9, 1994.
Xue, H. Y.; Yuan, L.; Cao, Y. J.; Fan, Y. P. Chen X. L. \& Huang, X. Z. Resveratrol ameliorates renal injury in spontaneously hypertensive rats by inhibiting renal micro-inflammation. Biosci. Rep., 36(3):e00339, 2016.

\author{
Corresponding author: \\ Dr. Mohammad Reza Salahshoor \\ Department of Anatomical Sciences \\ Medical School \\ Kermanshah University of Medical Sciences \\ Kermanshah \\ IRAN
}

Email: reza.salahshoor@yahoo.com

Received:09-05-2017

Accepted:14-09-2017 